\title{
LPS regulates the expression of glucocorticoid receptor $\alpha$ and $\beta$ isoforms and induces a selective glucocorticoid resistance in vitro
}

\author{
Maria Luisa Molina ${ }^{1,2+}$, Julia Guerrero ${ }^{2 \dagger}$, John A. Cidlowski ${ }^{3}$, Héctor Gatica ${ }^{1}$ and Annelise Goecke ${ }^{1,2^{*}}$
}

\begin{abstract}
Background: This study was aimed to evaluate the effect of LPS in glucocorticoid receptor (GR) isoforms expression on different cell lines and PBMC from healthy donors in vitro and glucocorticoid sensitivity of PBMC in vitro.

Methods: U-2 OS cell lines expressing GR isoforms, different cell lines (CEM, RAJI, K562 and HeLa) or PBMC from healthy donors, were cultured or not with LPS. The expression of GRa and GR $\beta$ was evaluated by Western blot. Glucocorticoid sensitivity was evaluated in PBMC treated with LPS, testing genes which are transactivated or transrepressed by glucocorticoid. For transactivated genes (MKP1, FKBP5) PBMC were treated with Dexamethasone $100 \mathrm{nM}$ for $6 \mathrm{~h}$. The mRNA expression was measured by RT-PCR. For transrepressed genes (IL-8, GM-CSF), PBMC were cultured in Dexamethasone $100 \mathrm{nM}$ and LPS $10 \mu \mathrm{g} / \mathrm{ml}$ for $6 \mathrm{~h}$ and protein expression was measure by ELISA.

Results: GR isoforms were induced in U-2 OS cells with a greater effect on GRa expression. Both isoforms were also induced in CEM cells with a tendency to a greater effect on GRB. LPS induced only the expression of GRa in Raji and HeLa cells, and in PBMC, with no effect in K562 cells. LPS induced a loss of glucocorticoid inhibitory effect only on the secretion of GM-CSF.

Conclusion: LPS in vitro differentially modulates the expression of GR isoforms in a cell specific manner. In PBMC from healthy donors LPS induces an approximately two times increase in the expression of GRa and a loss of the glucocorticoid inhibitory effect on the secretion of GM-CSF, without affecting other glucocorticoid responses evaluated.
\end{abstract}

Keywords: Lipopolysaccharide, Glucocorticoid receptor, Glucocorticoid resistance, Acute inflammation

\section{Background}

Glucocorticoids (GC) have been used as anti-inflammatory and immunosuppressive agents [1]. However, the sensitivity to $\mathrm{GC}$ actions varies among individuals and even in the same patient at different time points. The mechanisms mediating changes in GC sensitivity are not completely understood [2]. A better understanding of the factors that could influence the cell response to GC is relevant to adapt

\footnotetext{
* Correspondence: igoecke@hcuch.cl

${ }^{\dagger}$ Equal contributors

${ }^{1}$ Rheumatology Section, Internal Medicine Department, Clinical Hospital, University of Chile, Santiago, Chile

${ }^{2}$ Physiology and Biophysics Disciplinary Program, ICBM, Faculty of Medicine, University of Chile, Santiago, Chile

Full list of author information is available at the end of the article
}

GC therapy to different requirements in patients suffering autoimmune/inflammatory diseases.

The GC actions are mediated through the activation of intracellular glucocorticoid receptors (GR). The genomic structure of the single GR gene described in humans consists of 9 exons. Alternative splicing of exon 9 (exon $9 \alpha$ or $9 \beta$ ) results in the synthesis of 2 homologous mRNAs and protein isoforms, termed GR $\alpha$ and GR $\beta$ [3]. After GC binds GR $\alpha$, it binds as a homodimer to DNA, regulating the expression of the linked gene. GR $\alpha$ can also modulate gene expression by interacting with other transcription factors such as AP-1 and NF-kB, exerting most of the anti-inflammatory actions by this mechanism [4-7]. GR $\beta$ differs from GR $\alpha$ only in its carboxi-terminus sequence. This difference renders to GR $\beta$ a role as a dominant 
negative inhibitor of GR $\alpha$ activity. Therefore, a relative over-expression of the GR $\beta$ isoform could play a role in the regulation of target cell sensitivity to GC $[8,9]$. Indeed, studies have demonstrated that GR $\beta$ expression is elevated in patients with chronic inflammatory diseases associated with $\mathrm{GC}$ resistance e.g. asthma, inflammatory bowel disease and nasal polyps [10-14].

It has long been proposed that infectious episodes could trigger relapses in autoimmune diseases $[15,16]$. Our group has demonstrated a transient increased expression of GR $\beta$ in peripheral blood mononuclear cells (PBMC) from septic patients. We also showed that septic serum influence GC sensitivity, favoring the expression of GR $\beta$ in association with a GC resistant state $[17,18]$. Number of factors, present in serum from septic patients, such as cytokines, bacterial products and $\mathrm{GC}$, either by themselves or in combination could be responsible for these effects.

Webster et al. [19] showed that TNF- $\alpha$ and IL-1 induced the expression of both GR isoforms mRNA in HeLa and CEM-C7 cell lines, but the increase of the expression of GR $\beta$ was greater than GR $\alpha$ in those conditions. Other proinflammatory cytokines has also been reported to increase the expression of GR $\beta$ in vitro, such as IL-7, IL-18, and the combination of IL-2 and IL-4 in PBMC, and IL-8 in human neutrophils [13, 20, 21]. Interestingly, these cytokine treatments resulted in decreased sensitivity to GC in these cell types [13, 19-21]. Also, bacterial superantigens and bacterial toxins have been reported to increase the expression of GR $\beta[22,23]$.

Septic serum also contains fragments of bacteria which are recognized by innate immune system [24]. In our study, serum samples were obtained mostly from patients where a gram-negative infection was either suspected, due to the primary septic source or demonstrated by culture [18]. TLR4 recognizes lipopolysaccharides (LPS) present in gram-negative bacteria leading to the subsequent induction of the initial inflammatory response [25]. Therefore, the influence of septic serum on GR and GC cell sensitivity in our study could have been the consequence of the activation of TLR4 by LPS.

It is known that GC secreted endogenously by the adrenal gland restrict the responses to TLR [26]. Multiple mechanisms have been described for the GC interference with TLRs signaling [27, 28]. However, if TLR activation influences GR expression or GC sensitivity, has been scarcely studied. Indirect evidence of an effect of TLR activation on GR isoforms expression comes from two studies were an up regulation of GR $\beta$ expression was reported in vivo after the exposure to TLR4 agonist. One, in a septic animal model induced by LPS injection [29], and the other studying children with respiratory syncytial virus (RSV) infection, another known agonist of TLR4 [30]. However, it should be noted that after the induction of sepsis, and in children with RSV infection, changes in metabolic parameters, as well as cytokines, toxins and stress hormones levels are expected. Therefore, it is unclear the cause of GR isoforms modulation in both situations. The effect of LPS has been tested in vitro in bone marrow-derived macrophages and nasal mucosa fibroblasts with contradictory results, but it has not been evaluated on PBMC or lymphocytes in vitro [31, 32].

In this report, we evaluated the effect of LPS, a TLR4 agonist, on GR $\alpha$ and GR $\beta$ expression in different cell lines and PBMC from healthy donors in culture. We also explore the effect of LPS on GC cell sensitivity in vitro.

\section{Methods}

\section{Cell culture and transfection}

Human cell lines (CEM, K562, Raji and HeLa) were obtained from American Type Culture Collection, U-2 OS from Dr. Marcel Shaaf, and PBMC from healthy donors. CEM, K562, Raji cells and PBMC were grown in RPMI-1640 medium (GIBCO), supplemented with $10 \%$ fetal calf serum (FCS), $4 \mathrm{mM} \mathrm{L-glutamine,100} \mathrm{U/ml}$ penicillin, $100 \mu \mathrm{g} / \mathrm{ml}$ streptomycin at $37{ }^{\circ} \mathrm{C}$ in a $5 \% \mathrm{CO}_{2}$ humidified atmosphere. HeLa and U-2 OS cells were grown in DMEM-F12 medium (Invitrogen Life Technologies) containing 10\% FCS, glutamine, penicillin and streptomycin as described above.

Cell viability was $>95 \%$, determined by trypan blue exclusion staining, in cultures in the presence or not of LPS.

U-2 OS cell lines stably expressing human GR $\alpha$ or GR $\beta$ isoform were generated as previously described [33].

\section{Mononuclear cell extraction}

Peripheral venous blood samples $(30 \mathrm{ml})$ from healthy volunteers were collected and PBMC were isolated by density gradient centrifugation (Ficoll-Paque Plus, Amersham Bioscience). Written informed consent was previously obtained from all volunteers, according to the Declaration of Helsinki.

\section{Stimulation with LPS}

U-2 OS, CEM, K562, Raji, HeLa cells and PBMC $\left(2 \times 10^{6}\right.$ cells $\left./ \mathrm{ml}\right)$ were cultured with LPS from E.coli serotype O111:B4 (Sigma-Aldrich) at 0.1, 1, $10 \mu \mathrm{g} / \mathrm{ml}$; or only the vehicle as control, for $24 \mathrm{~h}$.

\section{GC sensitivity assay}

PBMC treated previously with or without LPS for $24 \mathrm{~h}$ were washed twice with PBS $1 \mathrm{X}$ and then GC sensitivity was evaluated by measuring: 1) Dexamethasone (DEX) induction of FKPB5 and MKP1 mRNA expression. Briefly, PBMC were cultured in the presence or absence of DEX $100 \mathrm{nM}$ for $6 \mathrm{~h}$, then FKPB5 and MKP1 mRNA expression was evaluated by qPCR. 2) DEX inhibition of 
LPS induced IL-8 and GM-CSF release by ELISA. Briefly PBMC were re-stimulated with $10 \mu \mathrm{g} / \mathrm{ml}$ of LPS for $6 \mathrm{~h}$ in presence or absence of DEX $100 \mathrm{nM}$. After incubation, cells were centrifuged and supernatant were collected and stored until the ELISA assay.

\section{Western blot analysis}

Cells were harvested and lysed using RIPA buffer (50 mM Tris pH 8.0, $150 \mathrm{mM} \mathrm{NaCl}, 1 \%$ Tween 20, 0.5\% SDS) containing protease inhibitors $(0.1 \mathrm{mM}$ phenylmetthylsulfonyl fluoride, $1 \mu \mathrm{g} / \mathrm{ml}$ aprotinin, $1 \mu \mathrm{M}$ pepstatin, $1 \mu \mathrm{M}$ leupeptin). Proteins $(50 \mu \mathrm{g})$ were resolved by electrophoresis through $10 \%$ polyacrylamide gels and transferred to nitrocellulose membranes as previously described [18]. Membranes were blocked in PBS 1X containing 10\% nonfat dry milk and $0,1 \%$ Tween 20, and incubated overnight at $4^{\circ} \mathrm{C}$ with a purified polyclonal rabbit anti-hGR antiserum (dilution 1:1000 to 1:2000) [34], specific polyclonal rabbit anti-GR $\alpha$ antibodies (dilution 1:200) (GR P-20: sc1002; Santa Cruz Biotecnology Inc., Santa Cruz, CA, USA), or specific polyclonal rabbit anti-GR $\beta$ antibodies (dilution 1:500) (PA3-514; Affinity BioReagents, Golden, CO, USA.); and $1 \mathrm{~h}$ at room temperature with mouse monoclonal anti $\beta$-actin (dilution 1:40,000) (Santa Cruz Biotecnology, Inc). Secondary biotinilated polyclonal antibodies against rabbit or mouse IgG (DAKO) were used for GR and $\beta$-actin detection, respectively. Films were densitometrically analyzed using Image J (Scion Corp.) and normalized to $\beta$-actin as loading control.

\section{Quantitative real-time PCR analysis}

Total RNA was isolated using Trizol Reagent (Invitrogen) according to the manufacturer's instructions. RNA concentration was determined by spectrophotometry and integrity of RNA by agarose gel electrophoresis. One $\mu \mathrm{g}$ of RNA was reverse transcribed using ImPromII $^{\mathrm{TM}}$ Reverse Transcription System (Promega). PCR analysis was performed in triplicate for each experiment with Brilliant SYBR Green in the Mx3000P ${ }^{\circ}$ real-time PCR system (Stratagene, La Jolla, CA). The primers used for RT-PCR were MKP1: 5'-GGTTCTTCTAGGAGTA GACA-3' (upstream) and 5'-GTACATCAAGTCCA TCTGAC-3' (downstream); FKPB5: 5' -TTGAGGAG GGGCCGAGTT-3' (upstream) and 5'-AAAAGGCCA AGGAGCACAAC-3' (downstream); h18S (housekeeping): 5'-GATATGCTCATGTGGTGTTG-3' (upstream) and 5'-AATCTTCTTCAGTCGCTCCA-3' (downstream). Relative mRNA levels for each sample were quantified using the threshold cycle $\left(C_{t}\right)$ approach and normalized with respect to h18S RNA.

\section{IL-8 and GM-CSF release quantification}

Immunoreactive IL- 8 and GM-CSF were determined on the supernatants of PBMC from the GC sensitivity assay by ELISA according to the manufacturer's instructions (Pierce Biotechnology, Inc.). Data are presented as the average of triplicate results. The lower limit of detection was $2 \mathrm{pg} / \mathrm{ml}$ for both assays.

\section{Statistic analysis}

All data are presented as medians with interquartile range and range of at least three independent experiments. Data were analyzed using Student's t test for normally distributed data and the Mann-Whitney test for nonparametric data, considering a p-value $<0.05$ statistically significant.

\section{Results}

LPS regulates the expression of GRa and GR $\beta$ isoforms in U-2 OS transfected cells

Western blot analysis of total proteins from human osteosarcoma cell line lacking endogenous GR (parental U-OFF cells, line 1), transfected with GR $\alpha$ (U-2 OS alpha, line 2) or GR $\beta$ (U-2 OS beta, line 3) using different antiGR antibodies is showed in Fig. 1a. When an antibody common to both GR isoforms was used, a protein of 90-95 kDa was detected in cells stably expressing GR $\alpha$ or GR $\beta$ isoform, but not in parental U-OFF cells. When an antibody specific for GR $\beta$ was used, a protein of $\sim 90 \mathrm{kDa}$ was identified only in U-2 OS beta cells.

To evaluate whether LPS stimulation modified GR $\alpha$ or GR $\beta$ protein expression in these cells, U-2 OS alpha or U-2 OS beta cells were cultured with different concentrations of LPS $(0.1,1$ or $10 \mu \mathrm{g} / \mathrm{ml})$. After $24 \mathrm{~h}$ the expression of GR $\alpha$ and GR $\beta$ was evaluated by Western blot with specific antibodies for each isoform. Figure $1 b$ shows that all concentrations of LPS induced at least a significant 6 fold increased expression of GR $\alpha$ (median 6.23, range 5.99-6.41 for LPS $0.1 \mu \mathrm{g} / \mathrm{ml}$, median 6.04, range 5.76-6.18 for LPS $1 \mu \mathrm{g} / \mathrm{ml}$, median 6.04, range 5.96-6.23 for LPS $10 \mu \mathrm{g} / \mathrm{ml}$; $p=0.002)$. LPS at low concentrations, but not LPS $10 \mu \mathrm{g} / \mathrm{ml}$, induced a significant increase of smaller magnitude in GR $\beta$ protein expression (LPS $0.1 \mu \mathrm{g} / \mathrm{ml}$ : median 1.25 , range $1.23-1.72$; LPS $1 \mu \mathrm{g} / \mathrm{ml}$ : median 1.23 , range $1.15-1.27 ; p=0.002$ ) (Fig. 1c).

\section{LPS regulates the expression of GRa and GR $\beta$ isoforms in} immune and epithelial cell lines

To assess whether LPS modulates the expression of GR isoforms in cells constitutively expressing this receptor, a monocytic cell line (K562) and two human cell lines of lymphoid origin (CEM and Raji) were used. These cells were treated or not with $10 \mathrm{ng} / \mathrm{ml}$ or $10 \mu \mathrm{g} / \mathrm{ml}$ of LPS for $24 \mathrm{~h}$. As shown in Fig. 2, LPS treatment induced a different response in the human immune cells studied. In $\mathrm{K} 562$ there was no change in the expression of GR isoforms at $10 \mathrm{ng} / \mathrm{ml}$ and $10 \mu \mathrm{g} / \mathrm{ml}$ of LPS (Fig. 2a). In 

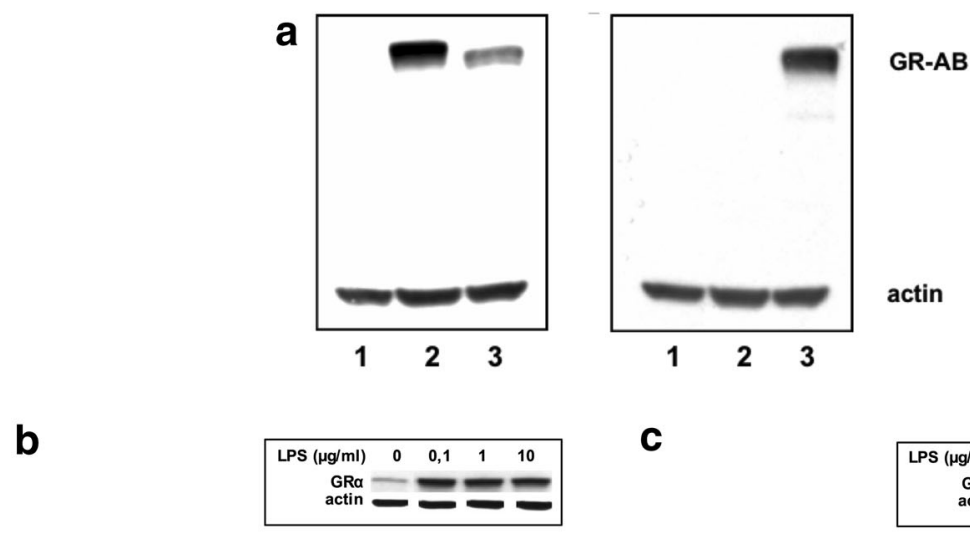

C
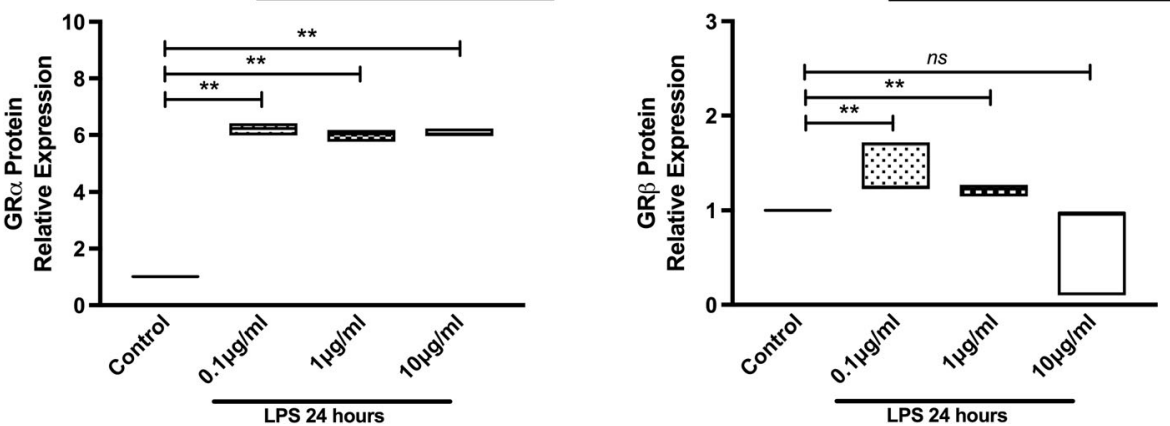

Fig. 1 LPS regulates the expression of GRa and GRß isoforms in U-2 OS transfected cells. a. Western blot of total proteins of parental U-OFF cells (line 1), U-2 OS alpha cells (line 2) and U-2 OS beta cells (line 3) are shown. On the left panel, a common antibody to GR was used and on the right panel a specific GR $\beta$ antibody was used. U2-OS alpha (b) and US-OS beta (c) cells were stimulated with LPS for $24 \mathrm{~h}$. The expression of GRa and GRß was determined by Western blot. The median values of three different experiments, plotted as values relative to control are shown. ${ }^{*} p<0.05$ and ${ }^{* *} p<0.01$

Raji cells there was a significant increase in only GR $\alpha$ expression at both concentrations used (LPS $10 \mathrm{ng} / \mathrm{ml}$ : median 1.57, range 1.29-1.66, $p=0.01$; LPS $10 \mu \mathrm{g} / \mathrm{ml}$ : median 1.98, range $1.91-2.55, p=0.03$ ) (Fig. 2b). In CEM cells there was an increase in the expression of both GR isoforms, being only statistically significant at LPS $10 \mu \mathrm{g} / \mathrm{ml}$ (GR $\alpha$ : median 1.18, range 0.99-1.63, $p=0.002$; GR $\beta$ : median 1.38 , range 1.10-1.55, $p=0.002$ ) (Fig. 2c).

In HeLa cells, an epithelial cell line, there was a significant increase only in GR $\alpha$ expression (median 1.86, range 1.02-2.37, $p=0.002$ ), with no change in GR $\beta$ expression when treated with $10 \mu \mathrm{g} / \mathrm{ml}$ of LPS for $24 \mathrm{~h}$ (Additional file 1).

\section{LPS regulates the expression of GRa in PBMC from healthy individuals}

We examined whether LPS modulates de expression of GR proteins isoforms in PBMC from healthy individuals. As shown in Fig. 3a, LPS $10 \mu \mathrm{g} / \mathrm{ml}$ treatment significantly increased GR $\alpha$ protein expression (median 1.95, range $1.04-4.35, p=0.007$ ), while GR $\beta$ protein expression was not modified. When PBMC were stimulated with LPS $10 \mathrm{ng} / \mathrm{ml}$, a similar result was obtained as mentioned before (Fig. 3b).
LPS modifies DEX sensitivity depending on the gene studied To assess whether LPS modify DEX sensitivity in PBMC from healthy individuals, we evaluated genes known to be transactivated o transrepressed by GC. The expression of two genes known to be up regulated by DEX, MKP-1 and FKPB5 were first tested. PBMC were stimulated or not with LPS $10 \mu \mathrm{g} / \mathrm{ml}$ for $24 \mathrm{~h}$, followed by $6 \mathrm{~h}$ of DEX 100 nM. DEX induced the expression of MKP-1 and FKPB5 mRNA in PBMC previously treated or not with LPS, but LPS pretreatment did not modify the inducing effect of DEX on MKP-1 (Control 4.82 \pm 1.1 vs LPS $3.76 \pm 1.6$ fold increase, $p=0.66$ ) (Fig. 4a) and FKPB5 (Control $16.69 \pm 7.6$ vs LPS $15.62 \pm 8.5$ fold increase, $p=0.95)$ mRNA expression (Fig. 4b).

To evaluate LPS effect in DEX sensitivity in genes known to be down-regulated by GC, we test DEX capacity to inhibit LPS induced IL-8 and GM-CSF protein expression. PBMC from healthy individuals were first stimulated or not with LPS $10 \mu \mathrm{g} / \mathrm{ml}$ for $24 \mathrm{~h}$ and then re-stimulated for $6 \mathrm{~h}$ with LPS $10 \mu \mathrm{g} / \mathrm{ml}$ and DEX 100 nM. As show in Fig. 5, DEX inhibited LPS induced expression of GM-CSF when PBMC were not pretreated with LPS $(0.64 \pm 0.18$ fold increase respect to control, $p=0.0022$ ), while DEX in PBMC pretreated with LPS did not inhibited LPS induced expression of this 

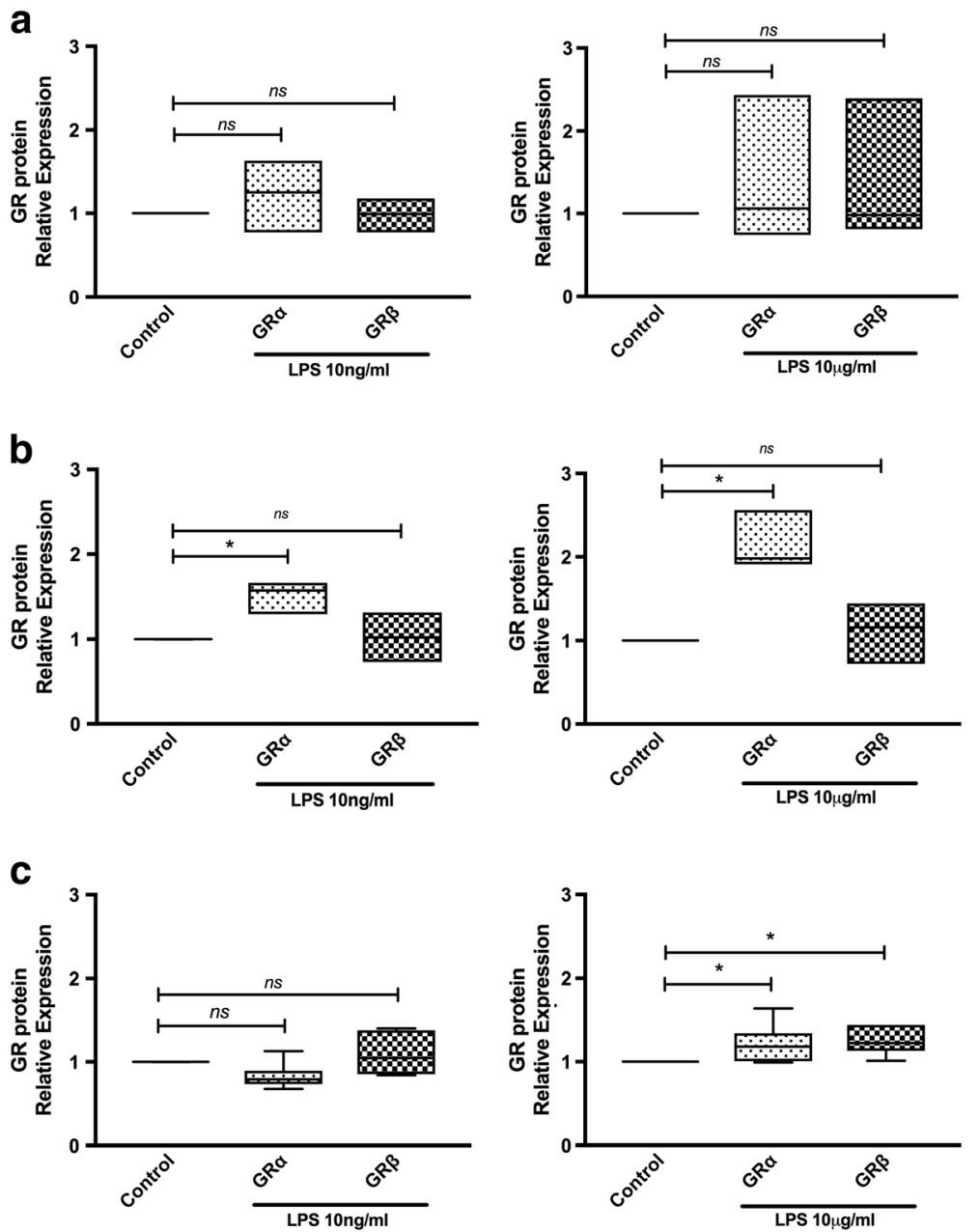

Fig. 2 LPS regulates the expression of GRa and GRß isoforms in immune cell lines. K562 (a), Raji (b), CEM (c) cells were cultured with LPS for $24 \mathrm{~h}$. The expression of GRa and GRß was determined by Western blot. The median values of three different experiments, plotted as values relative to control are shown. ${ }^{*} p<0.05$ and ${ }^{* *} p<0.01$

cytokine $(0.92 \pm 0.27$ fold increase respect to control, $p=0.36$ ) (Fig. 5b). The inhibitory effect did not change in PBMC pretreated with LPS when IL-8 was evaluated (Fig. 5a).

\section{Discussion}

Infectious episodes in patients with autoimmune diseases have been always a challenge. Not only because these patients are prone to more severe infections since they commonly are receiving immunosuppressive drugs such as GC, but also because frequently a flare is triggered. Since GC are important in the treatment of autoimmune diseases and also are a key factor in the response to infections, it is important to understand how an infection can influence the cell response to GCs.

This study has shown that LPS, present in Gamnegative bacteria cell wall, is able to differentially regulate the expression of $\mathrm{GR} \alpha$ and $\mathrm{GR} \beta$ in different cell lines and PBMC from healthy donors in culture. LPS induced both, GR $\alpha$ and GR $\beta$ in transfected cells (Fig. 1b and $\mathrm{c}$ ), but with an approximately four times greater effect on GR $\alpha$ expression. Some other groups have evaluated the effect of LPS on the expression of GR. Haim et al. showed that LPS on bone marrow-derived macrophages induced preferentially the expression of $\mathrm{GR} \beta$, resulting in a partial GC resistance [31]. However, Fernández-Bertolín et al., have shown that LPS $10 \mu \mathrm{g} / \mathrm{ml}$ did not modify the expression of GR on nasal mucosa fibroblasts, but it did induce a GC resistance for some but not all GC actions tested [32]. We therefore evaluated the effect of LPS on different cell lines relevant in the immune system. As is shown in Fig. 2, LPS in CEM cells ( $\mathrm{T}$ cell line) induced both, GR $\alpha$ and GR $\beta$ isoforms expression at the same concentrations used by Fernandez-Bertolin et al. [32], with a tendency to a greater effect on GR $\beta$, similar to the results of Haim et 


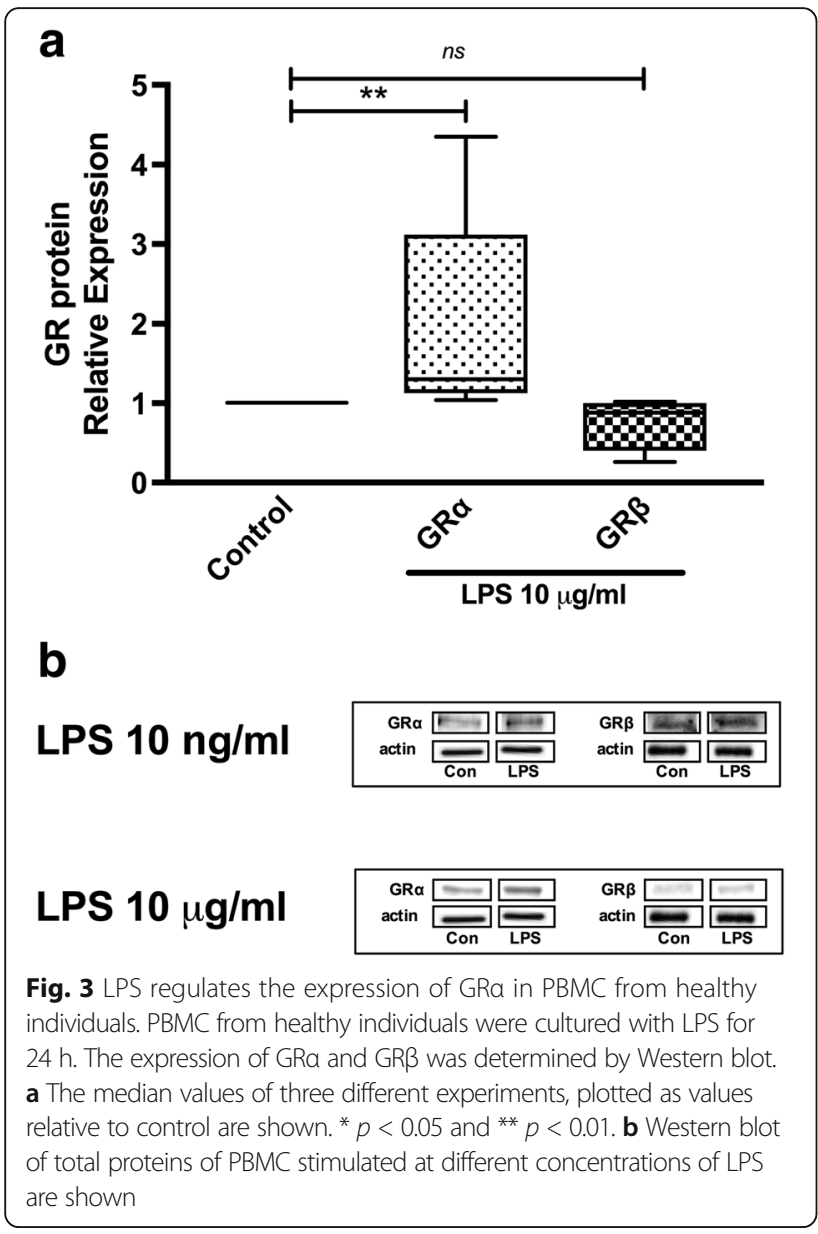

al. in macrophages. However LPS induced only the expression of GR $\alpha$ in Raji (B cell line) and HeLa (epithelial cell line) cells (Additional file 1), with no effect in the expression of either isoforms in K562 cells. Therefore, our results and what has been reported previously demonstrate that LPS can affect the expression of the GR isoforms, but this is a cell type specific response.

Since in normal circumstances $\mathrm{T}$ cells, B cells and monocytes will coexist when exposed to LPS, influencing each other, we decided to evaluate the effect of LPS on PBMC in vitro. Figure 3 shows that in these conditions there was an almost two time increase in GR $\alpha$ expression with no change in GR $\beta$. This effect is opposite to the effect of serum from septic patients, which induced preferentially GR $\beta$ expression on PBMC from healthy donors [19]. There are several possible explanations for this apparent contradiction. For instance, LPS is just one of the components of the serum of patients with septic states. In an inflammatory process induced by LPS there are many mediators such as cytokines, chemokines, lipid mediators, and reactive oxygen species among others that participate in the inflammatory process [35]. Any of these components could modulate the expression of GR
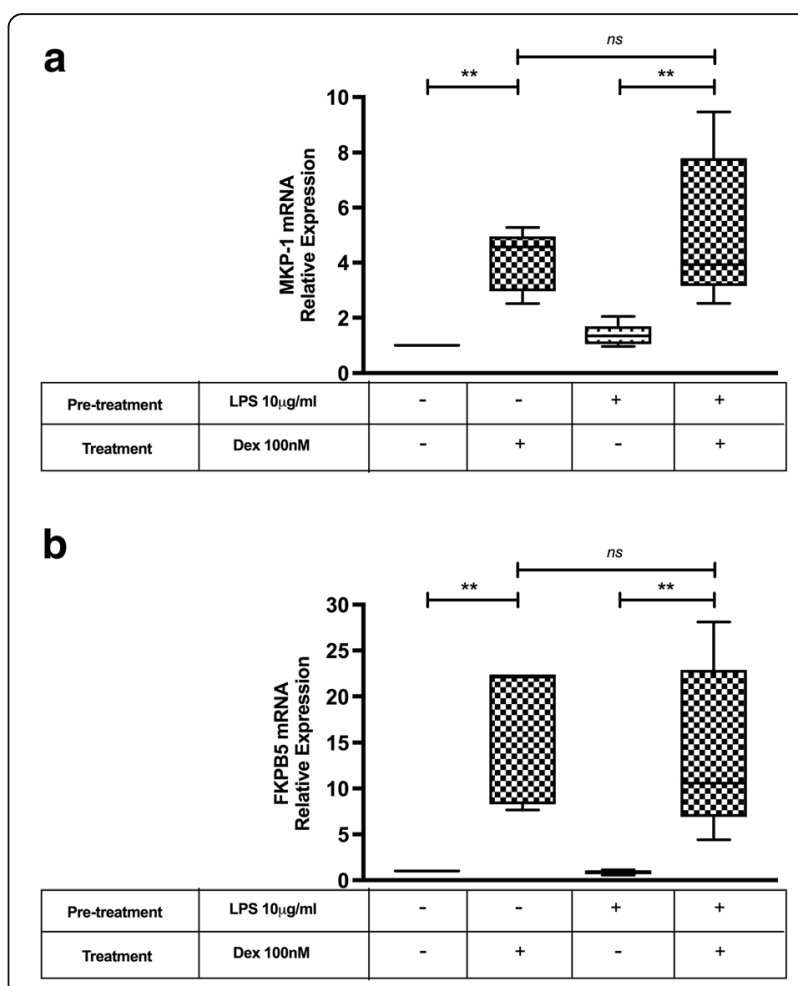

Fig. 4 GC Sensitivity Assay in Transactivated Genes. PBMC from healthy individuals were cultured for $24 \mathrm{~h}$ with or without LPS, follow for Dex $100 \mathrm{nM}$ for 6 h. MKP1 (a) and FKPB5 (b) mRNA expression was analyzed by RT-PCR. The median values of three different experiments, plotted as values relative to control, are shown. ${ }^{*} p<0.05$ and ${ }^{* *} p<0.01$

isoforms, and even depending on the concentration balance of these mediators, different responses could be elicited.

The GR $\alpha$ commonly has been described as the active GR isoform which mediates most of known GC actions, while GR $\beta$ can exert a negative dominant action over GR $\alpha$. Therefore, we expected that LPS would induced an increase sensitivity to GC actions on PBMC. Surprisingly our results showed that LPS treatment induced a loss of GC inhibitory effect on the production of GM-CSF. This resistance to $\mathrm{GC}$ effects was not generalized, since the inhibitory effect on the production of IL-8 or the induction of MKP-1 and FKPB-5 were maintained (Figs. 4 and 5). The effects of GC even when mediated by GR, are not only dependent on the ratio of expression of GR $\alpha$ and $\beta$. They can also be altered by nuclear translocation, changes in GR affinity, phosphorylation, among others [6, 36]. Therefore, it is possible that one or several of this factors could be involved in the GC loss of inhibition of GM-CSF induced by LPS. Indeed, in NM fibroblast, Fernández-Bertolin et al. showed that LPS 10 $\mu \mathrm{g} / \mathrm{ml}$ treatment lead to a reduced dexamethasoneinduced GR $\alpha$ nuclear translocation and a decreased GILZ expression without changing the GR $\alpha / G R \beta$ 


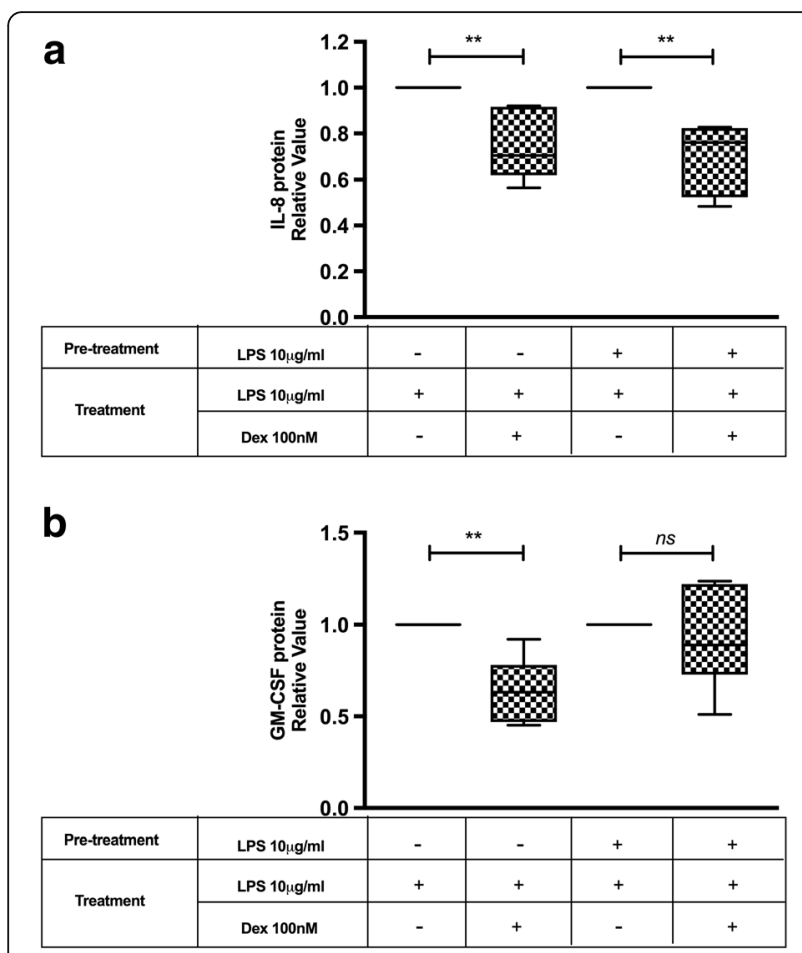

Fig. 5 GC Sensitivity Assay in transrepressed genes. PBMC from healthy individuals were cultured for $24 \mathrm{~h}$ with or without LPS, follow by DEX $100 \mathrm{nM}$ and LPS $10 \mathrm{\mu g} / \mathrm{ml}$ for $6 \mathrm{~h}$. IL-8 (a) and GM-CSF (b) content in the culture media was measure by ELISA. The median values of three different experiments, plotted as values relative to control are shown. ${ }^{*} p<0.05$ and ${ }^{*} p<0.01$

expression and maintaining dexamethasone's induction effect on MKP-1 and GILZ expression. Therefore, they also showed a GC resistant state limited to some but not all GC effects which was not associated to a change on GR expression [32].

It is also interesting that Armstrong et al., showed that even when most cytokines maintain a normal sensitivity to $\mathrm{GC}$ actions in macrophages from COPD patients a $\mathrm{GC}$ resistance was demonstrated for GM-CSF [37].

\section{Conclusions}

In summary our study showed that LPS in vitro modulates the expression of GR $\alpha$ and GR $\beta$ isoforms in a cell specific manner. In PBMC from healthy donor LPS induces the expression of GR $\alpha$ with no change of expression of GR $\beta$. It also induces a loss of GC inhibitory effect on the secretion of GM-CSF without affecting GC induction of MKP1 or FKBP5.

From our results as well as others, it is important to note that GCs effects can be modulated in a cell and effect specific manner. Therefore, it is not possible when a particular change of GC effects is observed under certain condition, to extrapolate those findings to other $\mathrm{GC}$ actions.

\section{Additional file}

Additional file 1: LPS regulates the expression of GRa and GR $\beta$ isoforms in a epithelial cell line. HeLa cells were cultured with LPS for $24 \mathrm{~h}$. The expression of GRa and GRß was determined by Western blot. The median values of three different experiments, plotted as values relative to control are shown. ${ }^{*} p<0.05$ and ${ }^{* *} p<0.01$. (TIFF $128 \mathrm{~kb}$ )

\section{Abbreviaitons}

DEX: Dexamethasone; GC: Glucocorticoids; GR: Glucocorticoid receptor; LPS: Lipopolysaccharides; PBMC: Peripheral blood mononuclear cells; RSV: Respiratory syncytial virus

\section{Acknowledgements}

We thank Ms. Rosario Flores for her technical assistance.

\section{Funding}

This work was supported by FONDECYT 108-0529.

\section{Availability of data and materials}

Please contact the corresponding author for data request.

\section{Authors' contributions}

$M L M, J G$ and $A G$ equally contributed to the design of the study and the writing of the manuscript. MLM performed in vitro experiments with PBMC and sensitivity tests to glucocorticoid and JG performed in vitro experiments with naive and transfected cell lines. AG and JC contributed to the revision of the article and its intellectual content. HG contributed to the elaboration of the statistical analysis and interpretation of data. All authors have read and aproved the final manuscript before submission.

Ethics approval and consent to participate

The study was approved by Fondecyt-Conicyt Bioethics Advisory Committee on April 4th, 2008

\section{Consent for publication}

Not applicable.

\section{Competing interests}

The authors declare that they have not competing interests.

\section{Publisher's Note}

Springer Nature remains neutral with regard to jurisdictional claims in published maps and institutional affiliations.

\section{Author details}

${ }^{1}$ Rheumatology Section, Internal Medicine Department, Clinical Hospital, University of Chile, Santiago, Chile. ${ }^{2}$ Physiology and Biophysics Disciplinary Program, ICBM, Faculty of Medicine, University of Chile, Santiago, Chile. ${ }^{3}$ Department of Health and Human Services, National Institute of Environmental Health Sciences, National Institutes of Health, Research Triangle Park, NC, USA.

Received: 10 May 2017 Accepted: 28 September 2017

Published online: 16 October 2017

\section{References}

1. Buttgereit F, Straub RH, Wehking M, Burmester GR. Glucocorticoids in the treatment of rheumatic diseases: an update on the mechanisms of action. Arthritis Rheum. 2004:50:3408-17.

2. Gross KL, Lu NZ, Cidlowski JA. Molecular mechanisms regulating glucocorticoid sensitivity and resistance. Mol Cell Endocrinol. 2009:300:7-16.

3. Hollenberg SM, Weinberger C, Ong ES, Cerelli G, Oro A, Lebo R, et al. Primary structure and expression of a functional human glucocorticoid receptor cDNA. Nature. 1985;318:635-41.

4. Pujols L, Mullol J, Torrego A, Picado C. Glucocorticoid receptors in human airways. Allergy. 2004;59:1042-52. 
5. De Bosscher K, Vanden Berghe W, Haegeman G. The interplay between the glucocorticoid receptor and nuclear factor-kappaB or activator protein -1 : molecular mechanisms of gene repression. Endocr Rev. 2003;24:488-522.

6. Leung DY, Bloom JW. Update on glucocorticoid action and resistance. J Allergy Clin Immunol. 2003;111:3-22.

7. Busillo JM, Cidlowski JA. The five Rs of glucocorticoid action during inflammation: ready, reinforce, repress, resolve, and restore. Trends Endocrinol Metab. 2013;24:109-19.

8. Oakley RH, Jewell CM, Yudt MR, Bofetiado D, Cidlowski JA. The dominant negative activity of the human glucocorticoid receptor beta isoform. Specificity and mechanisms of action. J Biol Chem. 1999;274:27857-66.

9. Yudt MR, Jewell CM, Bienstock RJ, Cidlowski JA. Molecular origins for the dominant negative function of human glucocorticoid receptor beta. Mol Cell Biol. 2003;23:4319-30.

10. Hamid QA, Wenzel SE, Hauk PJ, Tsicopoulos A, Wallaert B, Lafitte JJ, et al. Increased glucocorticoid receptor beta in airway cells of glucocorticoidinsensitive asthma. Am J Respir Crit Care Med. 1999:159:1600-4.

11. Goleva E, Li LB, Eves PT, Strand MJ, Martin RJ, Leung DY. Increased glucocorticoid receptor beta alters steroid response in glucocorticoidinsensitive asthma. Am J Respir Crit Care Med. 2006;173:607-16.

12. Honda M, Orii F, Ayabe T, Imai S, Ashida T, Obara T, et al. Expression of glucocorticoid receptor beta in lymphocytes of patients with glucocorticoid-resistant ulcerative colitis. Gastroenterology. 2000;118:859-66.

13. Orii F, Ashida T, Nomura M, Maemoto A, Fujiki T, Ayabe T, et al. Quantitative analysis for human glucocorticoid receptor alpha/beta mRNA in IBD. Biochem Biophys Res Commun. 2002;296:1286-94.

14. Hamilos DL, Leung DY, Muro S, Kahn AM, Hamilos SS, Thawley SE, et al. GRbeta expression in nasal polyp inflammatory cells and its relationship to the antiinflammatory effects of intranasal fluticasone. J Allergy Clin Immunol. 2001;108:59-68.

15. Samarkos M, Vaiopoulos $\mathrm{G}$. The role of infections in the pathogenesis of autoimmune diseases. Curr Drugs Targets Inflamm Allergy. 2005;4:99-103.

16. Doria A, Sarzi-Puttini P, Shoenfeld Y. Infections, rheumatism and autoimmunity: The conflicting relationship between humans and their environment. Autoimmun Rev. 2008:8:1-4

17. Goecke A, Guerrero J. Glucocorticoid receptor beta in acute and chronic inflammatory conditions: clinical implications. Immunobiology. 2006;211:85-96.

18. Guerrero J, Gatica HA, Rodriguez M, Estay R, Goecke IA. Septic serum induces glucocorticoid resistance and modifies the expression of glucocorticoid isoforms receptors: a prospective cohort study and in vitro experimental assay. Crit Care. 2013:17:R107.

19. Webster JC, Oakley RH, Jewell CM, Cidlowski JA. Proinflammatory cytokines regulate human glucocorticoid receptor gene expression and lead to the accumulation of the dominant negative beta isoform: a mechanism for the generation of glucocorticoid resistance. Proc Natl Acad Sci U S A. 2001;98:6865-70.

20. Leung DY, Hamid Q, Vottero A, Szefler SJ, Surs W, Minshall E, et al. Association of glucocorticoid insensitivity with increased expression of glucocorticoid receptor beta. J Exp Med. 1997;186:1567-74.

21. Strickland I, Kisich K, Hauk PJ, Vottero A, Chrousos GP, Klemm DJ, et al. High constitutive glucocorticoid receptor beta in human neutrophils enables them to reduce their spontaneous rate of cell death in response to corticosteroids. J Exp Med. 2001;193:585-93.

22. Fakhri S, Tulic M, Christodoulopoulos P, Fukakusa M, Frenkiel S, Leung DY, et al. Microbial superantigens induce glucocorticoid receptor beta and steroid resistance in a nasal explant model. Laryngoscope. 2004;114:887-92.

23. Fakhri S, Christodoulopoulos P, Tulic M, Fukakusa M, Frenkiel S, Leung DY, et al. Role of microbial toxins in the induction of glucocorticoid receptor beta expression in an explant model of rhinosinusitis. J Otolaryngol. 2003;32:388-93.

24. Van Amersfoort ES, Van Berkel TJ, Kuiper J. Receptors, mediators, and mechanisms involved in bacterial sepsis and septic shock. Clin Microbiol Rev. 2003;16:379-414

25. Poltorak A, He X, Smirnova I, Liu MY, Van Huffel C, Du X, et al. Defective LPS signaling in $\mathrm{C} 3 \mathrm{H} / \mathrm{HeJ}$ and $\mathrm{C} 57 \mathrm{BL} / 10 \mathrm{ScCr}$ mice: mutations in Tlr4 gene. Science. 1998;282:2085-8.

26. Chrousos GP. The hypothalamic-pituitary-adrenal axis and immunemediated inflammation. N Engl J Med. 1995;332:1351-62.

27. Abraham SM, Lawrence $T$, Kleiman A, Warden P, Medghalchi M, Tuckermann J, et al. Antiinflammatory effects of dexamethasone are partly dependent on induction of dual specificity phosphatase 1. J Exp Med. 2006;203:1883-9.

28. Ogawa S, Lozach J, Benner C, Pascual G, Tangirala RK, Westin S, et al. Molecular determinants of crosstalk between nuclear receptors and toll-like receptors. Cell. 2005;122:707-21.
29. Kamiyama K, Matsuda N, Yamamoto S, Takano K, Takano Y, Yamazaki H, et al. Modulation of glucocorticoid receptor expression, inflammation, and cell apoptosis in septic guinea pig lungs using methylprednisolone. Am J Physiol Lung Cell Mol Physiol. 2008;295:L998-L1006.

30. Diaz PV, Pinto RA, Mamani R, Uasapud PA, Bono MR, Gaggero AA, et al. Increased expression of the glucocorticoid receptor $\beta$ in infants with RSV bronchiolitis. Pediatrics. 2012;130:804-11.

31. Haim YO, Unger ND, Souroujon MC, Mittelman M, Nuemann D. Resistance of LPS-activated bone marrow derived macrophages to apoptosis mediated by dexamethasone. Sci Rep. 2014;10:4323.

32. Fernández-Bertolín L, Mullol J, Fuentes-Prado M, Roca-Ferrer J, Alobid I, Picado C, et al. Effect of lipololysaccharide on glucocorticoid receptor function in control nasal mucosa fibroblasts and in fibroblasts from patients with chronic rhinosinusitis with nasal polyps and asthma. PLoS One. 2015;10:e0125443.

33. Lu NZ, Cidlowski JA. Translational regulatory mechanisms generate Nterminal glucocorticoid receptor isoforms with unique transcriptional target genes. Mol Cell. 2005;18:331-42.

34. Cidlowski JA, Bellinghan DL, Powell-Oliver FE, Lubahn DB, Sar M. Novel antipeptide antibodies to the human glucocorticoid receptor: recognition of multiple receptor forms in vitro and distinct localization of cytoplasmic and nuclear recpetors. Mol Endocrinol. 1990;4:1427-37.

35. Cohen J. The immunopathogenesis of sepsis. Nature. 2002:420:885-91.

36. Kadmiel M, Cidlowski JA. Glucocorticoid receptor signaling in health and disease. Trends Pharmacol Sci. 2013:34:518-30.

37. Armstrong J, Sargent C, Singh D. Glucocorticoid sensitivity of lipopolysaccharide-stimulated chronic obstructive pulmonary disease alveolar macrophages. Clin Exp Immunol. 2009;158:74-83.

\section{Submit your next manuscript to BioMed Central and we will help you at every step:}

- We accept pre-submission inquiries

- Our selector tool helps you to find the most relevant journal

- We provide round the clock customer support

- Convenient online submission

- Thorough peer review

- Inclusion in PubMed and all major indexing services

- Maximum visibility for your research

Submit your manuscript at www.biomedcentral.com/submit
) Biomed Central 